УДК 332.146.3 : 353.9

Забарна Е.М. д. е. н., професор, Завідувач кафедри економічних систем і управління інноваційним розвитком Zabarna E., Doctor of Economics, Professor Head of the chair of economic systems and management of innovative development https://orcid.org/0000-0002-2659-5909

\title{
ТЕРИТОРІАЛЬНІ ГРОМАДИ В ЄВРОПЕЙСЬКОМУ ТРАНСКОРДОННОМУ ПPOCTOPI
}

\author{
Одеський національний політехнічний університет
}

Реформа адміністративно-територіального устрою та місцевого самоврядування належать до кола найактуальніших проблем України. Виходячи з цього, в даній роботі досліджено вплив адміністративнотериторіальної реформи в Україні на формування та розвиток територіальних громад. Визначено, що метою оптимізації економіки, яка заснована на принципово новій для України системі територіального устрою та відповідній йому активізації транскордонного співробітництва є створення ефективної системи влади в адміністративно-територіальних одиницях, здатної забезпечити сприятливі можливості для стійкого соціально-економічного розвитку усіх територій шляхом раціонального використання їхнього потенціалу на основі формування спроможних територіальних громад.

Ціллю даної статті є дослідження існуючих теорій та наукових концепцій щодо формування адекватного вимогам сьогодення територіального устрою в Україні на основі створення умов для ефективного господарювання спроможних територіальних громад та реальної транскордонної співпраці в європейському просторі.

Основною ідеєю нового регіоналізму визначено перетворення регіонів в головних суб'єктів реалізації соціально-економічних програм розвитку, що забезпечується шляхом надання регіонам широких повноважень (принцип субсидіарності). Одним зі сценаріїв налагодження міцних міжрегіональних зв'язків, які відповідатимуть вимогам інтеграції як регіону, так і країни в цілому у загальноєвропейський простір $€$ налагодження прикордонного співробітництва в усіх сферах життєдіяльності територіальної громади. Показано основні напрямки співпраці прикордонних територіальних громад країни. Запропоновано інноваційний підхід до активізації транскордонного співробітництва 3 європейським вектором розвитку українських територіальних громад - формування регіональної мережі Прикордонних консультаційних центрів (Платформи) з можливістю надання онлайн консультацій і навчання.

Ключові слова: адміністративно-територіальна реформа, децентралізація, територіальна громада, розвиток, європейський транскордонний простір.

\section{TERRITORIAL COMMUNITIES IN THE EUROPEAN CROSS-BORDER AREA}

\section{Odessa National Polytechnic University}

Reform of the administrative-territorial system and local self-government are among the most pressing issues of Ukraine. On that basis, the impact of administrative-territorial reform in Ukraine on the formation and development of territorial communities was researched in the paper. It was defined that the purpose of optimizing the economy, which is based on a fundamentally new for Ukraine system of territorial organization and the corresponding intensification of cross-border cooperation is to create an effective system of government in administrative-territorial units, able to provide favorable opportunities for sustainable socio-economic development of all territories by means of rational usage of their potential based on formation of capable territorial communities.

The purpose of this article is to study existing theories and scientific concepts on the formation of adequate to the current requirements territorial structure in Ukraine on the basis of creating conditions for effective management of sustainable territorial communities and real cross-border cooperation in the European space.

The main idea of the new regionalism is determined to be the transformation of regions into the key unsubs of implementation of socio-economic development programs, which is ensured by giving the regions broad powers (the principle of subsidiarity). One of the scenarios for establishing strong interregional ties that will meet the requirements of integration of both the region and the country as a whole into the European space is the establishment of frontier cooperation in all spheres of life of the territorial community. The main directions of cooperation of frontier territorial communities of the country are shown. An innovative approach to intensifying cross-border cooperation with the European vector of development of Ukrainian territorial communities is 
suggested - the formation of a regional network of Border Advisory Centers (Platforms) with the possibility of providing online consultations and training.

Key words: administrative-territorial reform, decentralization, territorial community, development, European cross-border area.

Постановка проблеми у загальному вигляді i iï зв'язок 3 важливими науковими та практичними завданнями. Нове сучасне розуміння територіального устрою України на основі активного використання просторового підходу позначається усвідомленнями особливостей географічного розміщення продуктивних сил України та специфікою функціонування прикордонних територій. Позитивним рухом відзначається розуміння ключових причин та проблем вітчизняної економіки, які зосереджені довкола досі діючої системи регіонального розподілу. Метою оптимізації економіки, яка заснована на принципово новій для України системі територіального устрою та відповідній активізації транскордонного співробітництва $\epsilon$ створення ефективної системи влади в адміністративно-територіальних одиницях, здатної забезпечити сприятливі можливості для стійкого соціально-економічного розвитку усіх територій шляхом раціонального використання їхнього потенціалу на основі формування спроможних територіальних громад.

Адміністративно-територіальний устрій нашої країни та сформована на цій основі система організації публічної влади не сприяла реформам в системі роботи органів місцевого самоврядування, не створювала самодостатній та стійкий фундамент розвитку територіальних громад як підгрунтя для державного розвитку. Децентралізація, реформа адміністративно-територіального устрою та місцевого самоврядування належать до кола найактуальніших проблем України. Це складна і глибока реформа, яка розбудовує всю систему управління країною. Суть явища децентралізації полягає у делегуванні повноважень від вищих чинів з метою покращення рівня контролю за використанням бюджетних коштів та виконання своїх обов'язків державними структурами [1].

Аналіз останніх досліджень у яких започатковано вирішення проблеми. Наукові підходи щодо регіонального розвитку як основи всіх подальших концепцій і теорій розвитку територій почали формуватися у другій половині XX ст. До того часу в більшості країн переважав галузевий підхід, який і визначав напрями державної регіональної політики. В основі вказаної теорії лежать класичні, неокласичні та кейнсіанські підходи, які були прийняті у світі для пошуку ефективних моделей регіонального розвитку починаючи 350 -х років. До економічних криз середини $70-\mathrm{x}$ років XX ст. теорія «точок» регіонального розвитку вдало застосувалась у багатьох державах, які нині є членами Європейського Союзу. Втім на думку фахівців [2], іiі слабкість швидко стала очевидною за умов поглиблення тривалої економічної кризи. Центри зростання залишились ізольованими у своїх регіональних економіках, а ініціативи, які були заохочені в ці регіони для структурної політики, виявились особливо вразливими до кризи. Отже, при розробці стратегій розвитку територій чи формуванні відповідних механізмів, слід враховувати світові економічні тенденції, «включеність» території у відносини з іншими регіонами та країнами. а також інші фактори впливу, які визначають умови функціонування території як відкритих систем, що формує умови для потужного розвитку транскордонного простору та відповідної співпраці [3].

Дослідження існуючих підходів та проблем здійснення реформ місцевого самоврядування в Україні досліджують такі вчені, як: В. Антоненко, Л. Бєлова, М. Білинська, В. Бодров, К. Ващенко, Р. Войтович, В. Загорський, В. Смельянов, Ю. Іванченко, В. Мамонова, І. Рожкова, С. Романюк, О. Рудік, С.Попов, А. Попок, Н. Протасова, Ю. Сурмін, С. Телешун, В. Толкованов, В. Шульга. Вивченню та аналізу специфіки транскордонної співпраці 3 регонами України присвячено роботи I. Артьомова, 3. Варналій, В. Куценко, В. Ляшенко, Ю.Макогон, Н. Микули, С Пирожков та ін. Проте, формування в Україні потужних територіальних громад, які мають стати активними суб'єктами в європейському транскордонному просторі, отже, поштовхом 
для активного територіального розвитку України не достатньо досліджено та потребує змістовного аналізу та розробки відповідних науково обгрунтованих пропозицій.

Ціллю даної статті $\epsilon$ дослідження існуючих теорій та наукових концепцій щодо формування адекватного вимогам сьогодення територіального устрою в Україні на основі створення умов для ефективного господарювання спроможних територіальних громад та реальної транскордонної співпраці в європейському просторі.

Виклад основного матеріалу дослідження 3 повним обгрунтуванням отриманих наукових результатів. Забезпечення подальшого розвитку місцевого самоврядування має передбачати формування потужного первинного суб' єкта місцевого самоврядування - самодостатньої територіальної громади, яка б володіла достатніми для саморозвитку матеріальними і фінансовими ресурсами. Згідно з оцінками фахівців, в Україні, актуальним стало питання необхідності реформування системи адміністративно-територіального устрою, що зростає у процесі проголошеного політичного курсу на європейську інтеграцію. Федонюк С.В. наголошує, що «не існує універсальної моделі територіальної організації адміністрування, оптимально пристосованої до вимог членства у ЄС», але вона повинна відповідати вимогам для забезпечення реалізації регіональної політики за принципами:

- політика має мати надійну законодавчу основу;

- можливість розв'язання довгострокових структурних задач;

- ринкова орієнтація регіональної політики;

- просторова спрямованість [4].

За словами польського політолога Олександра Неліцького Євросоюз висуває «вимогу результативності», тобто головний принцип полягає у тому, що система державного управління мусить працювати ефективно [5]. Варто відзначити, що існуюча в Україні система організації влади на місцевому рівні не відповідає загальноприйнятим європейським принципам, закладеним в Свропейській Хартії місцевого самоврядування [6], яка є частиною українського законодавства (ратифікована Верховною Радою України у 1997р.). Невиконання положень Хартії, і як наслідок, взятих на себе зобов'язань, є однією з перешкод на шляху реалізації курсу на інтеграцію до Європейського співтовариства, задекларованого Україною.

Існують приклади країн, яким чіткий план регіонального розвитку та успішне реформування дали можливість вступити до Свропейського Союзу. Наприклад, в Польщі вже з 2000 р. фінансова допомога СС становила близько 850 млн. $€$, а з 2002 p. - близько 6 млрд.€ щороку. Це стало можливим насамперед завдяки тому, що результатом проведеної адміністративно-територіальної реформи в Польщі стала трансформація країни з соціалістичної, побудованої на засадах жорсткої централізації, на державу, яка служить своїм громадянам і спираючись на самоврядні інститути та громадянське суспільство, дає можливість формувати й контролювати органи публічної влади.

Існує думка [7], про доцільність формування адміністративно-територіальних одиниць відповідно до Номенклатури статистичних територіальних одиниць (NUTS), розробленої для надання певним територіям фінансової допомоги Свропейського Союзу. Така позиція є чи не ключовою вимогою для інтеграції до ЄС. Сама концепція таких реформ грунтується на одному з основних європейських принципів - децентралізації центральної влади шляхом іiі зміцнення на рівні місцевого самоврядування та запровадження регіонального рівня самоврядування.

Власне за рахунок децентралізації, тобто передачі частини повноважень, їх фінансового забезпечення та відповідальності з рівня державного управління на рівень місцевого самоврядування або «local government», було досягнутого високого рівня ефективності управління розвитком територій.

Адміністративно-територіальний поділ країн $Є С$ формувався під впливом різноманітних факторів, серед яких географічний, економічний, демографічний, історичний та ін. Адміністративно-територіальний устрій є основою для організації 
сучасного державного управління, формування органів влади в державі, розбудови місцевого самоврядування.

Загалом сам по собі стандарт NUTS, як зазначає О. Г. Кучабський [7], створений для статистичних і фінансових цілей, не «скасовує» адміністративно-територіального поділу в будь-яких країнах $\mathrm{CC}$ і не містить однакового, обов'язкового для всіх державчленів, адміністративно-територіального розподілу, а лише стосуються створення регіональних адміністративно-територіальних одиниць, що відповідають класифікації NUTS. Система NUTS служить базою для порівняння рівнів соціально-економічного розвитку. Вона дозволяє оцінювати і порівнювати ефективність регіональної політики різних територій. NUTS поділяє територіальні одиниці $Є C$ на 5 категорій (рівнів). Три 3 них - NUTS-1 (суб'єкти федерації, автономні утворення, регіони), NUTS-2 (провінції, департаменти, урядові округи), NUTS-3 (графства, префектури), a NUTS-4 i NUTS -5 місцеві одиниці регіональної статистики ЄС. До кожного рівня рекомендована орієнтовна кількість населення: NUTS-1 - від 3 до 7 млн. жителів; NUTS-2 - від 800 тис. до 3 млн. жителів; NUTS-3 - від 150 тис. до 800 тис. жителів відповідно. Під NUTS-3, на більш деталізованому рівні, знаходяться районні муніципалітети, що мають назву «Місцеві адміністративні одиниці» (LAU) [8].

Отже, запровадження в практику державного управління розвитком регіонів будь-якої країни стандарту NUTS $є$ важливим кроком на шляху реформи місцевого самоврядування, регіонального управління та адміністративно-територіальної реформи. Що стосується України то впровадження цього стандарту дасть одразу декілька переваг для планування та реалізації можливих напрямків переформатування територіального устрою країни. Саме стандарт NUTS дасть змогу довести хибність багатьох тверджень щодо необхідності федералізації України і разом з тим дозволить сформувати ефективну модель регіональної організації влади що суттєво підвищить ефективність діяльності органів місцевого самоврядування та державних органів на локальних рівнях.

Власне, центральною ідеєю нового регіоналізму $є$ перетворення регіонів в головних суб'єктів реалізації соціально-економічних програм розвитку, інфраструктурних проєктів, програм в сфері охорони здоров'я, освіти і культури, що забезпечується шляхом надання регіонам широких повноважень (принцип субсидіарності). Головна властивість місцевого самоврядування має полягати в наданні «права та спроможності територіальної громади вирішувати питання місцевого значення під свою відповідальність або відповідальність створених нею органів» [9]. Найголовніший та універсальний принцип для громад сьогодні - не покладатися на допомогу з Центру. Починати варто з тверезої інвентаризацій та усвідомлення власних можливостей громади у створенні практичних умов для якнайшвидшого відновлення місцевої економіки.

Отримання внаслідок децентралізації можливості розпоряджатися ресурсом власного розвитку відкрило широке поле діяльності щодо втілення давно назрілих сподівань на оновлення середовища життєдіяльності громади - комунальної, соціальної, шляхової інфраструктури. Проте замикатися в рамках цілей та завдань, які формуються та реалізуються лише в межах громад - завжди обмеження для розвитку. У певний момент неминуче момент, коли певні дії 3 благоустрою наштовхуються на межу доступності фінансових ресурсів, або, навіть за наявності коштів, вже не працюють на посилення регіональної згуртованості та задоволеність членів громади ії розвитком. Діє класичний для закритої системи закон зниження граничної віддачі - коли кожне нове вкладення дає дедалі менший ефект. Одним зі сценаріїв налагодження міцних міжрегіональних звязків, які відповідатиме вимогам інтеграції як регіону, так і країни в цілому у загальноєвропейський простір є налагодження прикордонного співробітництва в усіх сферах життєдіяльності територіальної громади.

За визначенням «Свропейської рамкової конвенції про транскордонне співробітництво між територіальними общинами або властями», транскордонне 
співтовариство означає будь-які спільні дії, спрямовані на посилення та поглиблення добросусідських відносин між територіальними общинами або властями, які знаходяться під юрисдикцією двох або декількох Договірних Сторін, та на укладання 3 цією метою будь-яких необхідних угод або досягнення домовленостей [10]. В цілому, інтеграція України до Європейського простору можлива за умови тісного співробітництва між прикордонними територіальними общинами в таких галузях, як регіональний, міський та сільський розвиток, охорона навколишнього середовища, розвиток інфраструктури, взаємна допомога при надзвичайних ситуаціях, тощо. Слід зазначити, що специфікою транскордонної співпраці $\epsilon$ розуміння того, що вона $\epsilon$ забезпечує цілісність територіальної системи транскордонного регіону, а складники території одного транскордонного регіону можуть одночасно належати декільком територіальним системам [11, С.270].

Так, в Україні, засновано функціонування таких інституцій, як Агентство регіонального розвитку та транскордонного співробітництва, Агенція регіонального розвитку та Європейської інтеграції, Інститут «Схід-Захід» та інші. В якості прикладу спільних проектів можна навести такі:

- розробка комплексного українсько-угорського проєкту щодо противопаводкових заходів;

- через р. Тису, на українсько-угорському кордону, побудова транспортному мосту;

- створення системи гідроспоруд у прикордонних регіонах (спільний проєкт України, Угорщини, Румунії, Словаччини);

- будівництво міжнародного пункту пропуску на українсько-словацькому кордоні «Малі Селменці - Великі Селменці», а також автомобільного пункту пропуску «Смільниця - Кростенко»;

- запровадження транскордонної програми медико-соціальної реабілітації спільно з Угорщиною;

- створення інформаційно-туристичного центру в Закарпатті, тощо [12].

Однією з найбільш сучасних та ефективних форм організації транскордонної співпраці між територіальними утвореннями України та Європи є становлення, так званих, єврорегіонів (вони утворюються між громадами двох держав, які мають спільні кордони).

Інноваційним підходом до активізації транскордонного співробітництва 3 європейським вектором розвитку українських територіальних громад, на нашу думку, може стати формування регіональної мережі Прикордонних консультаційних центрів (Платформи) з можливістю надання онлайн консультацій і навчання (в тому числі через формування цільових груп задля проведення тренінгів та воркшопів). Окрім іншого, до такої Платформи можна приєднати територіальні громади інших держав (в межах спільних кордонів) та надавати інформацію певним цільовим аудиторіям щодо фінансових можливостей, готувати бізнес-плани, проєкти, подавати заявки на отримання фінансування та грантів, тощо.

3 метою підвищення ефективності консультацій доцільно також передбачити можливість формування звітів та накопичення певної аналітики. Платформа може надавати можливість всім, хто має фахові знання та практичний досвід, консультувати керівництво громад, а менеджерам-практикам - обирати та замовляти відповідного консультанта i спосіб навчання. Учасниками Платформи можуть виступати всі територіальні громади України та закордону, які зацікавлені в транскордонній співпраці, банки, постачальники матеріальних ресурсів, постачальники техніки та обладнання, інвестори, грантові проєкти, страхові компанії, університети, консультанти.

В такий спосіб формується абсолютно нова бізнес-модель консультаційних послуг - регіональна мережа, яка забезпечує синергію усіх учасників транскордонного простору в контексті ефективного функціонування територіальних громад. 
Висновки. Згідно 3 оцінками фахівців, не існує універсальної моделі територіальної організації адміністрування, оптимально пристосованої до вимог членства у СС, але вона повинна відповідати вимогам для забезпечення реалізації регіональної політики. ЄС висуває «вимогу результативності», тобто головний принцип полягає у тому, що система державного управління мусить працювати ефективно. Виходячи 3 цього, найбільш ефективною формою територіального устрою стає формування в Україні спроможних територіальних громад, діяльність яких спрямована на активне використання наявного потенціалу для підвищення добробуту населення та поштовху для розвитку країни в цілому. Враховуючи географічне розташування нашої країни та значну кількість прикордонних регіонів, особливого значення набувають процеси формування транскордонної співпраці між різними територіальними громадами України та об'єднаннями прилеглих до кордонів територій інших держав. 3 іншого боку, утворення такої організаційної форми як єврорегіон орієноване на координацію взаємних зусиль та узгодження конкретних дій у різних сферах життєдіяльності відносно національного законодавства і норм міжнародного права 3 метою вирішення загальних проблем для підвищення добробуту мешканців, що населяють його територію 3 обох боків кордону.

\section{Список бібліографічного опису}

1. Забарна Е.М. Децентралізація в Україні в контексті запровадження системи «регіональних студій» / Е.М.Забарна // Матеріали III міжнародної науково-практичної Інтернет-конференції «Суспільно-географічні чинники розвитку регіонів», 11-12 квітня 2019 р., м. Луцьк : Волиньполіграф, 2019. - С.122-124.

2. Регіональний розвиток та державна регіональна політика в Україні: стан і перспективи змін у контексті глобальних викликів та європейських стандартів політики. Аналітичний звіт. Проєкт ЄС «Підтримка політики регіонального розвитку в Україні». [Електронний ресурс]. https://fileview.fwdedn.com/?url=https\%3A\%2F\%2Fmail.ukr.net\%2Fapi\%2Fpublic\%2Ffile_view\%2Flist\%3Ftoken\%3DCY hjTbgzdwjekniresoKRTvyZqniIxviEHFlzedX1QhUzcWYIR9KfqCu2y_DFW1HYQJ-

k19ZxBtstIbgmSYF8MY_yGGe5nFhV5IpDA\%253AqN8SRx99CbbHXxsa\%26r\%3D1594826532643\&default_mode=view \&lang=ru\#start $=0$

3. Забарна Е. Регіональні ринки України в сучасних умовах господарювання / Е.Забарна // Європейський журнал економіки та менеджменту (Чехія). - 2019. - Том 5. Вип.1. - С.201-206.

4. Федонюк С. В. Адміністративно-територіальна реформа у процесі інтеграції з СС (на прикладі Польщі) / С. В. Федонюк // Досвід вступу Польщі до Європейського Союзу: уроки для України : матеріали Міжнар. круглого столу (21 трав. 2009 р.) / за ред. С. В. Федонюка. - Луцьк : Волин. нац. ун-т ім. Лесі Українки, 2009. - С. 60-72.

5. Неліцький О. Місцеве самоврядування у Польщі / О.Неліцький. [Електронний ресурс]. - Режим доступу: https://www.umww.pl/attachments/article/37103/UMWW_slowniczek_net.pdf

6. Свропейська хартія місцевого самоврядування в Україні: питання реалізації та контролю / The European Charter of Local Self-Government in Ukraine: Issues of Enforcement and Control / М. В. Гірняк. - Львів : Каменяр, 2004. - C.54-56.

7. Кучабський О. Г. Перспективи впровадження статистичної системи NUTS в Україні в контексті адміністративнотериторіальної реформи [Електронний ресурс]. http://www.nbuv.gov.ua/ejournals/dutp/20062/txts/REGIONALNE\%5C06kogkar.pdf.

8. Мамонова В. Аспекти самоврядування / В.Мамонова // Економіка України. - 2004. - № 5 (26). - С. 15-18.

10. Єврпоейська рамкова конвенція про транскордонне співробітництво між територіальними общинами або властями. [Електронний pecypc]. $\quad-\quad$ Режим доступу: file://C:/Users/Admin/Downloads/\%D0\%84\%D0\%B2\%D1\%80\%D0\%BE\%D0\%BF\%D0\%B5\%D0\%B9\%D1\%81\%D1\%8C $\% \mathrm{D} 0 \% \mathrm{BA} \% \mathrm{D} 0 \% \mathrm{~B} 0 \% 20 \% \mathrm{D} 1 \% 80 \% \mathrm{D} 0 \% \mathrm{~B} 0 \% \mathrm{D} 0 \% \mathrm{BC} \% \mathrm{D} 0 \% \mathrm{BA} \% \mathrm{D} 0 \% \mathrm{BE} \% \mathrm{D} 0 \% \mathrm{~B} 2 \% \mathrm{D} 0 \% \mathrm{~B} 0 \% 20 \% \mathrm{D} 0 \% \mathrm{BA} \% \mathrm{D} 0 \% \mathrm{BE} \%$ D0\%BD\%D0\%B2\%D0\%B5\%D0\%BD\%D1\%86\%D1\%96\%D1\%8F\%20\%D0\%BF\%D1\%80\%D0\%BE\%20\%D1\%82\%D1\% 80\%D0\%B0\%D0\%BD...\%20_\%20\%D0\%B2\%D1\%96\%D0\%B4\%2021.05.1980\%20(\%D0\%A2\%D0\%B5\%D0\%BA\%D1\% 81\%D1\%82\%20\%D0\%B4\%D0\%BB\%D1\%8F\%20\%D0\%B4\%D1\%80\%D1\%83\%D0\%BA\%D1\%83).pdf

11. Management of modern socio-economic systems. - Collective monograph. - Vol.1. Lithuania : Izdevnieciba "Baltija Publishing”, 2017. - 296 р. / Кухарська Н.О. Транскордонне співробітництво як форма розвитку економічних відносин України на регіональному рівні. - С. 263-291.

12. Розширення Європейського Союзу : вплив на відносини України з центральноєвропейськими сусідами / Інститут регіональних та євроінтеграційних досліджень «Єврорегіон Україна». - К. , 2004. - С.100-131.

\section{References}

1. Zabarna E. Detsenralizatsiya v Ukrayini v kontecsti zaprovadzhennya sistemy "regionalnyh studii" - Materiali III mizhnarodnoi naukovo-practichnoi konferentsii "Suspilno-geografichni chinniki rozvitku regioniv", Lutsk, 2019, pp.122-124. [in Ukrainian]

2. Regionalnyi rozvitok ta derzhavna politika v Ukrayini: stan s perspectyvy zmin u konteksti globalnyh vyklykiv ta evropeyskyh standartiv polityky. Analitychnyi zvit. Proekt ES "Pidtrymka polityky regionalnogo rozvitku v Ukrayini". Available https://fileview.fwdedn.com/?url=https\%3A\%2F\%2Fmail.ukr.net\%2Fapi\%2Fpublic\%2Ffile_view\%2Flist\%3Ftoken\%3DCY 
hjTbgzdwjekniresoKRTvyZqniIxviEHFlzedX1QhUzcWYIR9KfqCu2y_DFW1HYQJ-

k19ZxBtstIbgmSYF8MY_yGGe5nFhV5IpDA\%253AqN8SRx99CbbHXxsa\%26r\%3D1594826532643\&default_mode=view \&lang=ru\#start $=0$ [in Ukrainian]

3. Zabarna E. Regionalniye rynki Ukrayini v suchasnyh umovah gospodaryuvannya - Evropeyskiy zhurnal economicy ta menedzhmentu, Chehiya, vol.5, no. 1, pp. 201-206. [in Ukrainian]

4. Fedonuk S. Administrativno-terytorialna reforma v protsesy integratsiyi z ES (na prykladi Polshy). Dosvid vstupu Polshchy do Evropeyskogo Souzu: uroki dlya Ukrayini - Materuali mszhnarodnogo kruglogo stolu, Lutsk, 2009, pp. 60-72. [in Ukrainian]

5. Niletskiy O. Mistseve samovryaduvannya u Polshchi. Available at: https://www.umww.pl/attachments/article/37103/UMWW_slowniczek_net.pdf [in Ukrainian]

6. Tvropeyska hartuya mistsevogo samovryaduvannya v Ukrayiny: pytannya realizatziyi ta cotrolyu / The European Charter of Local Self-Government in Ukraine: Issues of Enforcement and Control / M. В. Гірняк. - Lviv, 2004, pp.54-56. [in Ukrainian] 7. Kuchabskiy O. Perspektivi vprovadzhennya statystychnoyi systemi NUTS v Ukrayini v konteksti administrativnoterritorialnoyi reformi. Available at: http://www.nbuv.gov.ua/ejournals/dutp/20062/txts/REGIONALNE\%5C06kogkar.pdf. [in Ukrainian]

8. Mamonova V. Aspecty samovryaduvannya - Economica Ukrayini, 2004, no. 5 (26), pp. 15-18. [in Ukrainian]

10. Evropeyska ramkova conventsiya pro transkordonne spivrobitnytztvo mizh terytorialnymy obshchinamy abo vlastyamy. Available

at:file:///C:/Users/Admin/Downloads/\%D0\%84\%D0\%B2\%D1\%80\%D0\%BE\%D0\%BF\%D0\%B5\%D0\%B9\%D1\%81\%D1\% 8C\%D0\%BA\%D0\%B0\%20\%D1\%80\%D0\%B0\%D0\%BC\%D0\%BA\%D0\%BE\%D0\%B2\%D0\%B0\%20\%D0\%BA\%D0\%BE $\% \mathrm{D} 0 \% \mathrm{BD} \% \mathrm{D} 0 \% \mathrm{~B} 2 \% \mathrm{D} 0 \% \mathrm{~B} 5 \% \mathrm{D} 0 \% \mathrm{BD} \% \mathrm{D} 1 \% 86 \% \mathrm{D} 1 \% 96 \% \mathrm{D} 1 \% 8 \mathrm{~F} \% 20 \% \mathrm{D} 0 \% \mathrm{BF} \% \mathrm{D} 1 \% 80 \% \mathrm{D} 0 \% \mathrm{BE} \% 20 \% \mathrm{D} 1 \% 82 \% \mathrm{D} 1$ $\% 80 \% \mathrm{D} 0 \% \mathrm{~B} 0 \% \mathrm{D} 0 \% \mathrm{BD} . . \% 20 \_\% 20 \% \mathrm{D} 0 \% \mathrm{~B} 2 \% \mathrm{D} 1 \% 96 \% \mathrm{D} 0 \% \mathrm{~B} 4 \% 2021.05 .1980 \% 20(\% \mathrm{D} 0 \% \mathrm{~A} 2 \% \mathrm{D} 0 \% \mathrm{~B} 5 \% \mathrm{D} 0 \% \mathrm{BA} \% \mathrm{D} 1$ $\% 81 \% \mathrm{D} 1 \% 82 \% 20 \% \mathrm{D} 0 \% \mathrm{~B} 4 \% \mathrm{D} 0 \% \mathrm{BB} \% \mathrm{D} 1 \% 8 \mathrm{~F} \% 20 \% \mathrm{D} 0 \% \mathrm{~B} 4 \% \mathrm{D} 1 \% 80 \% \mathrm{D} 1 \% 83 \% \mathrm{D} 0 \% \mathrm{BA} \% \mathrm{D} 1 \% 83$ ).pdf [in Ukrainian] 11. Management of modern socio-economic systems. - Collective monograph. - Vol.1. Lithuania : Izdevnieciba "Baltija Publishing", 2017. - 296 p. / Kuharska N. Transkordonne spivrobitnytztvo yak forma rozvitku ekonomichnyh vidnisyn Ukrayini na regionalnomu rivny, pp. 263-291. [in Ukrainian]

12. Rozshyrennya Evropeyskogo Souzu : vplyv na vidnosynu Ukrayini z tzentralnoevropeyskymi susidami / Instytut regionalnyh ta evrointegratziynyh doslidzhen "Evroregion Ukrayine", 2004, pp.100-131. [in Ukrainian]

Дата подання публікації 17.06.2020 p.

\title{
УДК 336.15
}

\section{JEL Classification: H6, H7, H77}

Самоховец М.П., к.э.н., доцент, доцент кафедры Samakhavets M. P. Candidate of Economic Sciences, Associate of Professor, Associate of Professor of the department https://orcid.org/0000-0002-4564-2424 Бухтик М.И., к.э.н., доцент, доцент кафедры Buhtik M. I. Candidate of Economic Sciences, Associate of Professor, Associate of Professor of the department https://orcid.org/0000-0001-8036-7985

Киевич А.В., д.э.н., профессор, профессор кафедры Kievich A.V. Doctor of Economic Sciences, Professor, Professor of the department https://orcid.org/0000-0003-4249-7644

\section{РАЗВИТИЕ МЕЖБЮДЖЕТНЫХ ОТНОШЕНИЙ В РЕСПУБЛИКЕ БЕЛАРУСЬ}

\section{Полесский государственный университет}

\begin{abstract}
Актуальность исследования межбюджетных отношений Республики Беларусь обосновано необходимостью изучения современного состояния и оценки финансовых отношений между бюджетами различных уровней бюджетной системы. Цель статьи - провести анализ и оценить параметры развития межбюджетных отношений в Республике Беларусь и обозначить основные характеристики их развития на современном этапе. Объект исследования - межбюджетные отношения в Республике Беларусь. Методы,
\end{abstract}

